Assiut University web-site: www.aun.edu.eg

\title{
OCCURRENCE OF SHIGELLA SPECIES IN RAW MILK AND KAREISH CHEESE WITH SPECIAL REFERENCE TO ITS VIRULENCE GENES
}

\author{
ZEINAB M. ABD-ELHAMED ${ }^{1}$ AND MANAL HASSAN THABET ${ }^{2}$ \\ ${ }^{1}$ Food Hygiene Dep. Agricultural Research Center, Animal Health Research \\ Institute (Assiut Provincial Lab.) \\ ${ }^{2}$ Bacteriology Dep. Agricultural Research Center, Animal Health Research \\ Institute (Assiut Provincial Lab.)
}

Received: 30 June 2020; Accepted: 26 July 2020

\begin{abstract}
A total number of 100 random samples of raw milk and kareish cheese (50 for each) were collected from Assiut city farms and dairy shops. Shigella species were isolated, confirmed biochemically and by using Polymerase Chain Reaction (PCR). Also two virulence genes; invasive gene (invC) and plasmid- encoded virulence gene (ipaH) were identified using PCR technique. 10 isolated strains of Shigella isolates (37\%) from dairy milk samples and 13 isolates (43\%) from kareish cheese were identified as following: S. dysenteriae, S. flexneri, $S$. sonnei and $S$. boydii. The two virulence genes; (invC) and (ipaH) were detected in only six and four strains of the identified Shigella species, respectively. Four of them had both the virulence genes (isolated from milk and cheese samples). Even though conventional culture is considered the gold standard for Shigella detection and the PCR method is a useful tool which complements detection of foodborne pathogens such as Shigella. Chitosan was evaluated in this study as antibacterial substance on the identified Shigella strains by inoculating it in pasteurized milk, using 3 different concentrations: $0.25,0.5$ and $1 \%$ of chitosan. Chitosan reduced the inoculated Shigella strain mean counts with highly significant effect $(P<0.01)$ at the $6^{\text {th }}$ day reached to $2.10 \pm 0.17,1.00 \pm 0.30$ and $<1 \log \mathrm{cfu} / \mathrm{ml}$ for $0.25,0.5$ and $1 \%$ chitosan concentrations, respectively; while at the $12^{\text {th }}$ day we noticed that chitosan concentration of $0.5 \%$ only was highly significant $(\mathrm{P}<0.05)$. Generally, the $0.5 \%$ chitosan concentration showed the highly reduction effect on the count and survival of the Shigella strain involved.
\end{abstract}

Keywords: Shigella, chitosan, antibacterial activities.

\section{INTRODUCTION}

Members of the genus Shigella, namely S. flexneri, S. dysenteriae, S. sonnei and $S$. boydii have caused and continue to be responsible for mortality and/or morbidity in high risk populations such as children, old aged people, toddlers in day-care centers and patients in custodial institutions (Kotloff, et al., 1999) .

Corresponding author: ZEINAB M. ABD-ELHAMED

E-mail address: z.shoret@gmail.com

Present address: Food Hygiene Dep. Agricultural Research center, Animal Health Research Institute (Assiut Provincial Lab.)
Virulence genes responsible for the pathogenesis of shigellosis may be located in the chromosome or on the inv plasmid borne by the organism. They are often multifactorial and coordinately regulated, and the genes tend to be clustered in the genome. Previously reported PCR-based detection methods concentrated mainly on the ipaH gene alone (Dutta, et al., 2001) or on ipaH and ial genes in two separate PCR assays (Sethabutr et al., 1993). As ial is found on the large inv plasmid which is prone to loss or deletions, this gene-based detection may give false negative results. 
$\mathrm{ipaH}$, on the other hand, is present on both the Shigella chromosome and on a large plasmid and hence, it is a more stable gene to detect. However, the sole presence of ipaH is not an absolute indicator of virulence as loss or deletion of the plasmid renders the bacterium noninvasive and therefore, avirulent. set1A and set1B are chromosomal genes encoding Shigella enterotoxin 1 (ShET1), which cause the watery phase of diarrhoea in shigellosis (Rhee, et al., 2001). ial and ipaH are responsible for directing epithelial cell penetration by the bacterium and for the modification of host response to infection, respectively (Hale, 1991). However, the advent of molecular biology assays, such as the Polymerase Chain Reaction (PCR), has made bacterial detection possible without the need for bacteria isolation. PCR has become a powerful diagnostic tool for detection of microorganisms in food and clinical-samples (Lampel and Orlandi, 2002).

Traditional antimicrobials have been utilized as preservatives to control microbial perils in the food industry. Despite the fact that these compounds, synthetic and semisynthetic, have been generally accepted, the unwanted side effects can't be ignored and don't fulfill the idea of "natural" or "healthy" food that consumers are progressively requesting. In this way, there is a requirement for new, increasingly proficient antimicrobials for use in food products to guarantee that consumers approach a safe food supply. Because of the negative effect from chemical preservatives, consideration has moved to the utilization of naturally-derived antimicrobial agents to control foodborne pathogens and preserving food. Natural antimicrobials are gotten from numerous sources, including animals as chitosan (Raybaudi-Massilia, et al., 2009 and Tiwari et al., 2009).

Chitosan a deacetylated products of chitin, is an adaptable food biopolymer that has discovered an assortment of utilizations in every aspect of the food sciences. Chitosan has numerous natural nutritional values for example, act as broad spectrum antimicrobial activities, antioxidant, cancer prevention agent promoting bioactivities against many chronic diseases, as hypercholesterolemia, hypertension, inflammation, immune diseases, etc., so consequently has been studied as a food preservative to improve food quality and expand the time span of usability of shortlived nourishment items (Shakeel and Saiqa, 2017). Chitosan is nontoxic and nonallergenic, so the body does not reject these compounds as foreign invaders. Biocompatibility, biodegradability and absorption properties of chitosan and its derivatives are much higher than synthetically substituted cellulose (Peter, 1995). So that in the food sciences, chitosan has an advantage over synthetic polymers, as it is considered as GRAS (Generally Recognized as Safe) by the Food and Drug Administration (FDA) (Shakeel and Saiqa, 2017).

The chitosan has been demonstrated that hydrophilicity in Gram-negative bacteria is significantly higher than in Gram-positive bacteria, making them most sensitive to chitosan. These findings are confirmed by several in vitro experiments in which Gramnegative bacteria appear to be very sensitive to chitosan, exhibiting increased morphological changes on treatment when compared to Gram-positives (Eaton et al., 2008; Simunek, et al., 2006 and $\mathrm{Hu}$ and Ganzle, 2018). The polycationic behavior of chitosan in an acidic medium is the main factor contributing to its antimicrobial activity. Due to its positive surface charges under acidic conditions, chitosan interacts with anionic components on the bacteria surface: for example, negatively charged lipopolysaccharides in the outer membrane of Gram-negative bacteria, and peptidoglycan and teichoic acid in the cell walls of Gram-positive bacteria. These electrostatic interactions produce the release of most of the proteinaceous materials from the cells. This potent effect was ascribed to the electrostatic interactions between the 
chitosan molecules and microbial cell membranes which led to the leakage of proteinaceous materials, consequently increasing chitosan penetration to the nucleus and binding to the DNA, thus inhibiting mRNA synthesis (Martinez et al., 2010).

Three antibacterial mechanisms have been proposed: i) the ionic surface interaction resulting in wall cell leakage; ii) the inhibition of the mRNA and protein synthesis via the penetration of chitosan into the nuclei of the microorganisms; and iii) the formation of an external barrier, chelating metals and provoking the suppression of essential nutrients to microbial growth. It is likely that all events occur simultaneously but at different intensities. The molecular weight (MW) and the degree of acetylation (DA) are also important factors in determining such activity. In general, the lower the MW and the DA, the higher will be the effectiveness on reducing microorganism growth and multiplication (Rejane et al., 2009).

The aim of this study was to investigate the presence of Shigella species in raw milk and kareish cheese with the application of PCR for simultaneous detection of Shigella invC, and ipaH virulence genes. In addition, evaluation of chitosan as antibacterial agent on Shigella strain in milk.

\section{MATERIALS AND METHOD}

\section{1-Sampling:}

A total of one hundred random samples of raw milk and kareish cheese collected from different farms, street vendors and dairy shops located in Assiut city: 50 samples each. Samples were kept in sterile plastic bags and transported in ice box to the laboratory. These samples were aseptically opened then were analyzed for presence of Shigella species.

\section{2- Isolation and identification of Shigella species:}

Samples of $25 \mathrm{~g}$ or $25 \mathrm{ml}$ was added to 225 $\mathrm{ml}$ GN broth with $3.0 \mu \mathrm{g}$ novo biocin $\backslash \mathrm{ml}$. Samples of cheese were weighed into filtered stomacher bags and then mixed with GN broth, suspension was held $10 \mathrm{~min}$ at room temp and shacked periodically then incubated in anaerobic jar at $42.0{ }^{\circ} \mathrm{C}$ in water bath for $20 \mathrm{~h}$ (Hall et al., 2001). Enrichment culture suspension was streaked on XLD Agar, and then incubated for $20 \mathrm{~h} \pm$ $4 \mathrm{~h}$ at $37^{\circ} \mathrm{C} \pm 1^{\circ} \mathrm{C}$. Characteristic colonies were picked for biochemical confirmation comprised of TSI agar with no $\mathrm{H}_{2} \mathrm{~S}$, Urea agar, Methyl red, Indol production and LLysine Decarboxylation.

\section{3-Molecular identification of Shigella isolates using PCR:}

This part was done in Molecular Biology Lab. (accredited by EGAC, ISO17025:2017), Animal Health Research Institute, Dokki, Giza, Egypt.

DNA extraction: DNA extraction from samples was performed using the QIAamp DNA Mini kit (Qiagen, Germany, GmbH) with modifications from the manufacturer's recommendations. Briefly, $200 \mu \mathrm{l}$ of the sample suspension was incubated with $10 \mu 1$ of proteinase $\mathrm{K}$ and $200 \mu \mathrm{l}$ of lysis buffer at 56 o $\mathrm{C}$ for $10 \mathrm{~min}$. After incubation, $200 \mu \mathrm{l}$ of $100 \%$ ethanol was added to the lysate. The sample was then washed and centrifuged following the manufacturer's recommendations. Nucleic acid was eluted with $100 \mu \mathrm{l}$ of elution buffer provided in the kit.

\section{4-Molecular identification of some virulence genes in the identified Shigella isolates: \\ Oligonucleotide Primer: Primers used were supplied from Metabion (Germany) are listed in table (l).}

PCR amplification: Primers were utilized in a 25- $\mu \mathrm{l}$ reaction containing $12.5 \mu \mathrm{l}$ of EmeraldAmp Max PCR Master Mix (Takara, Japan), $1 \mu \mathrm{l}$ of each primer of 20 pmol concentration, $4.5 \mu \mathrm{l}$ of water, and $6 \mu \mathrm{l}$ 
of DNA template. The reaction was performed in an Applied biosystem 2720 thermal cycler. Analysis of the PCR Products: The products of PCR were separated by electrophoresis on $1.5 \%$ agarose gel (Applichem, Germany, GmbH) in 1x TBE buffer at room temperature using gradients of $5 \mathrm{~V} / \mathrm{cm}$. For gel analysis, $15 \mu \mathrm{l}$ of the products was loaded in each gel slot. Generuler 100 bp DNA ladder (Fermentas, thermos, Germany) was used to determine the fragment sizes. The gel was photographed by a gel documentation system (Alpha Innotech, Biometra) and the data was analyzed through computer software

Table 1: Primers sequences, target genes, amplicon sizes and cycling conditions.

\begin{tabular}{|c|c|c|c|c|c|c|c|c|}
\hline \multirow{2}{*}{$\begin{array}{l}\text { Target } \\
\text { gene }\end{array}$} & \multirow[b]{2}{*}{ Primers sequences } & \multirow{2}{*}{$\begin{array}{l}\text { Amplified } \\
\text { segment } \\
\text { (bp) }\end{array}$} & \multirow{2}{*}{$\begin{array}{c}\text { Primary } \\
\text { denaturation }\end{array}$} & \multicolumn{3}{|c|}{ Amplification (35 cycles) } & \multirow{2}{*}{$\begin{array}{l}\text { Final } \\
\text { extension }\end{array}$} & \multirow[b]{2}{*}{ Reference } \\
\hline & & & & $\begin{array}{c}\text { Secondar } \\
\text { denaturation }\end{array}$ & Annealing & Extension & & \\
\hline \multirow{3}{*}{$\operatorname{inv} C$} & TGC CCA GTT TCT & \multirow{3}{*}{875} & \multirow{3}{*}{$\begin{array}{l}94^{\circ} \mathrm{C} \\
5 \mathrm{~min} .\end{array}$} & \multirow{3}{*}{$\begin{array}{l}94^{\circ} \mathrm{C} \\
30 \mathrm{sec} .\end{array}$} & \multirow{3}{*}{$\begin{array}{l}60^{\circ} \mathrm{C} \\
40 \mathrm{sec} .\end{array}$} & \multirow{3}{*}{$\begin{aligned} 72^{\circ} \mathrm{C} \\
45 \mathrm{sec} .\end{aligned}$} & \multirow{3}{*}{$\begin{array}{c}72^{\circ} \mathrm{C} \\
10 \mathrm{~min}\end{array}$} & \multirow{3}{*}{$\begin{array}{l}\text { Ojha et } \\
\text { al. }(2013)\end{array}$} \\
\hline & TCA TAC GC & & & & & & & \\
\hline & $\begin{array}{l}\text { GAA AGT AGC TCC } \\
\text { CGA AAT GC }\end{array}$ & & & & & & & \\
\hline \multirow{3}{*}{ ipaH } & GCCGGTCAGCCACC & \multirow{3}{*}{600} & \multirow{3}{*}{$\begin{array}{l}94^{\circ} \mathrm{C} \\
5 \mathrm{~min} .\end{array}$} & \multirow{3}{*}{$\begin{array}{l}94^{\circ} \mathrm{C} \\
30 \mathrm{sec} .\end{array}$} & \multirow{3}{*}{$\begin{array}{l}55^{\circ} \mathrm{C} \\
40 \mathrm{sec} .\end{array}$} & \multirow{3}{*}{$\begin{array}{l}72^{\circ} \mathrm{C} \\
45 \mathrm{sec} .\end{array}$} & \multirow{3}{*}{$\begin{array}{c}72^{\circ} \mathrm{C} \\
10 \mathrm{~min} .\end{array}$} & \multirow{3}{*}{$\begin{array}{c}\text { Jiménez } \\
\text { et al. } \\
\text { (2010) }\end{array}$} \\
\hline & CT CTGAGACTAC & & & & & & & \\
\hline & $\begin{array}{c}\text { GTTCCTTGACCGCCT } \\
\text { TTCCGTACCGT }\end{array}$ & & & & & & & \\
\hline
\end{tabular}

5- Effect of chitosan application on survival of Shigella spp. in milk:

1- Preparation of the tested strain:

Isolated and well identified shigella strain in this study which harboring invC and ipaH virulence genes was used (S. flexneri).

Bacterial dilutions were prepared as follows: $S$. flexneri strain was inoculated onto trypticase soy broth and incubated at $35^{\circ} \mathrm{C}$. One milliliter of the culture was serially diluted in sterile peptone buffer. Then the suspension was adjusted to bring turbidity to $0.5 \mathrm{McFarland}$ standards with a concentration of $10^{7} \mathrm{CFU} / \mathrm{ml}$ (as confirmed by the pour plate technique). From the previous diluted suspension tubes, the standard strain suspension of which $1 \mathrm{ml}$ may contain approximately about $2 \times 10^{5}$ $\mathrm{cfu} / \mathrm{ml}$ was used directly in the experimental groups of milk (Lampel, 2001).

\section{2- Preparation of Chitosan solutions:}

Chitosan capsules (70-95\% deacetylated) were purchased from Unifarma (Egypt). Chitosan solution was prepared by dispersing it in $0.25 \%$ acetic acid solution (Aliasghari et al., 2016). Concentrations of $0.25,0.5$ and $1 \%$ was prepared.

**Determination of the Minimum Inhibitory Concentration (MIC) of chitosan using agar well-diffusion method: (Balouiri et al., 2016).

The prepared bacterial suspension with $1 \times 10^{3} \mathrm{cfu} / \mathrm{ml}$ was streaked over the entire dried surface of Muller-Hinton agar plate using sterile swab. Six mm-diameter wells were punched aseptically with a sterile corkborer or a tip over the agar plates. Then 50 $\mu \mathrm{L}$ of the each prepared concentrations of chitosan solutions were poured into the wells. The plate was kept at a temperature of $4^{\circ} \mathrm{C}$ until the materials in the wells were completely diffused into the agar, and the plates were incubated aerobically at $37^{\circ} \mathrm{C}$ for $24 \mathrm{~h}$. The zone of inhibition was measured using a caliper and recorded. The smallest inhibitory zone was considered as the Minimum Inhibitory Concentration.

3-Effect of chitosan concentrations in pasteurized milk: 
Pasteurized milk samples were purchased from dairy shop and then pasteurized again in the laboratory, to carry out this work, milk is commonly heated to provide stability during storage and assure microbiological safety to consumers. We have evaluated the microbial status and $\mathrm{pH}$ of pasteurized milk stored at refrigerator temperature. Also, all the pasteurized milk samples showed negative phosphatase test.

After cooling, the sample was divided into 5 treatment groups; One $\mathrm{ml}$ of the previously prepared S. flexneri suspension mixed with $100 \mathrm{ml}$ of pasteurized milk and divided into suitable sterile jars except the fifth group was free from strain suspension and chitosan as a negative control. The first group was positive control jars without chitosan; the $2^{\text {nd }}, 3^{\text {rd }}$ and fourth groups were mixed by different chitosan concentrations $0.25,0.5$ and $1 \%$, and then all jars stored at $4^{\circ} \mathrm{c}$, examined for the count of shigella every three days until the end of experiment when the spoilage of the positive control group detected by clot on boiling test.

Statistical Analysis:

The statistical analysis was performed using programs GraphPad Prism 5.04 (GraphPad, Inc., San Diego, USA) and Statistical 12.0 (Dell, Inc., Tulsa, USA) after transforming of data to $\log _{10}$ values. The bacterial count represented by mean \pm SD (standard deviation). The means were separated using ANOVA and LSD except for the $9^{\text {th }}$ day where independent T-test was used by the Microsoft Excel Spreadsheet.

\section{RESULTS}

Table1: Incidence of isolated Shigella species in the examined samples $(n=100)$ :

\begin{tabular}{ccccc}
\hline Types of examined samples & $\begin{array}{c}\text { Number of } \\
\text { examined samples }\end{array}$ & $\begin{array}{c}\text { Number of } \\
\text { Positive samples }\end{array}$ & \multicolumn{2}{c}{ Isolated strains } \\
\cline { 5 - 6 } $\begin{array}{c}\text { Raw } \\
\text { milk }\end{array}$ & 50 & 27 & 10 & No. \\
\hline Kareish cheese & 50 & 30 & 13 & 43 \\
\hline Total & 100 & 57 & 23 & 40.4 \\
\hline
\end{tabular}

Table 2: Frequency distribution of the isolated Shigella species in the positive samples biochemically.

\begin{tabular}{|c|c|c|c|c|c|}
\hline \multirow{2}{*}{$\begin{array}{c}\text { Types of examined } \\
\text { samples }\end{array}$} & \multirow{2}{*}{$\begin{array}{l}\text { Number of } \\
\text { isolated strains }\end{array}$} & \multicolumn{4}{|c|}{ The isolated Shigella species } \\
\hline & & $\begin{array}{c}S . \\
\text { dysenteriae }\end{array}$ & S. flexneri & S. sonnei & S. boydii \\
\hline $\begin{array}{l}\text { Raw } \\
\text { milk }\end{array}$ & 10 & 1 & 3 & 6 & 0 \\
\hline Kareish cheese & 13 & 2 & 5 & 5 & 1 \\
\hline Total & 23 & 3 & 8 & 11 & 1 \\
\hline
\end{tabular}


Table 3: The occurrence of virulence Shigella species using PCR technique.

\begin{tabular}{ccccc}
\hline Examined samples & $\begin{array}{c}\text { Identified } \\
\text { strains by PCR }\end{array}$ & $\begin{array}{c}\text { invC } \\
\text { gene }\end{array}$ & $\begin{array}{c}\text { ipaH } \\
\text { gene }\end{array}$ & Both genes \\
\hline $\begin{array}{c}\text { Raw } \\
\text { Milk }\end{array}$ & 10 & 2 & 2 & 2 \\
\hline Kareish cheese & 13 & 4 & 2 & 2 \\
\hline
\end{tabular}

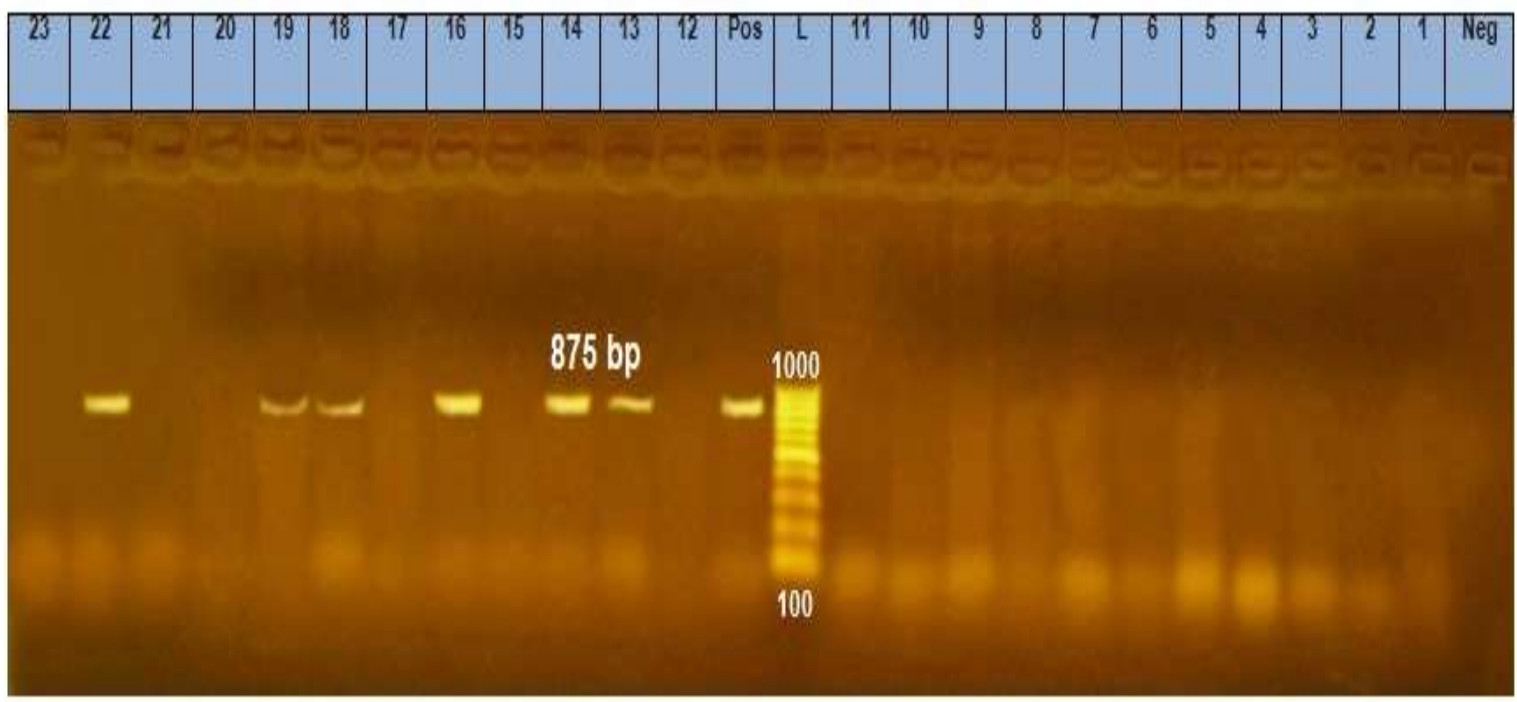

Photo 1: The amplified invC gene of Shigella recovered from milk and kareish cheese samples.

Lane L: Molecular marker; Lane pos: Positive control; Lane Neg: Negative control; Lanes 15, 17, 20, $\mathbf{2 1}, 23$ negative isolates for invC gene; Lane 13, 14, 16, 18, 19, 22: positive isolates for invC gene

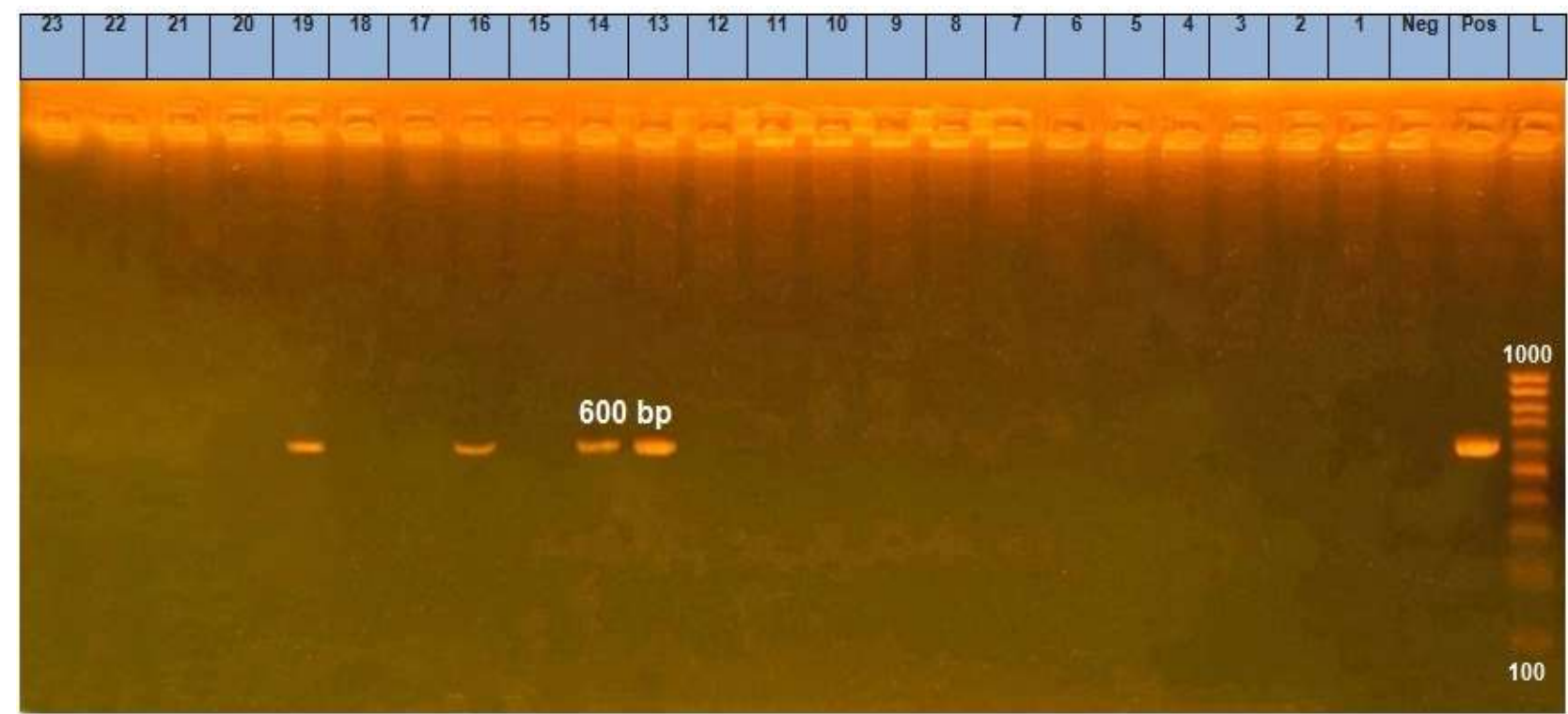

Photo 2: The amplified ipaH gene of Shigella recovered from milk and kareish cheese samples.

Lane L: Molecular marker; Lane pos: Positive control; Lane Neg: Negative control; Lanes 15, 17, 18, 20, 21, 22, 23 negative isolates for ipaH gene; Lane 13, 14, 16, 19: positive isolates for ipaH gene. 
Table 4: Effect of different concentrations of chitosan on the survival of Shigella strain in the pasteurized milk samples stored at $4{ }^{\circ} \mathrm{C}$

\begin{tabular}{ccccccc}
\hline $\begin{array}{c}\text { Chitosan } \\
\text { concentration }\end{array}$ & Zero time & $1^{\text {st }}$ day & $3^{\text {rd }}$ day & $6^{\text {th }}$ day & $9^{\text {th }}$ day & $12^{\text {th }}$ day \\
\hline \multirow{2}{*}{ Positive control } & $3.21^{\mathrm{a}}$ & $3.69^{\mathrm{a}}$ & $5.33^{\mathrm{a}}$ & $5.04^{\mathrm{a}}$ & $5.04^{\mathrm{a}}$ & $3.85^{\mathrm{a}}$ \\
& \pm 0.34 & \pm 0.09 & \pm 0.33 & \pm 0.17 & \pm 0.24 & \pm 0.22 \\
\hline \multirow{2}{*}{ Conc. $0.25 \%$} & 3.30 & 3.31 & $3.78^{\mathrm{b}}$ & $2.10^{\mathrm{b}}$ & $1.30^{\mathrm{b}}$ & $1.46^{\mathrm{b}}$ \\
& \pm 0.30 & \pm 0.17 & \pm 0.26 & \pm 0.17 & \pm 0.30 & \pm 0.15 \\
\hline \multirow{2}{*}{ Conc. $0.5 \%$} & 3.56 & 3.24 & $1.20^{\mathrm{c}}$ & $1.00^{\mathrm{c}}$ & $<1$ & $<1$ \\
\hline \multirow{2}{*}{ Conc. $1 \%$} & \pm 0.24 & \pm 0.47 & \pm 0.17 & \pm 0.30 & & $<1$ \\
& $3.86^{\mathrm{a}}$ & $3.17^{\mathrm{a}}$ & $1.36^{\mathrm{c}}$ & $<1$ & $<1$ & \pm 0.17 \\
\hline
\end{tabular}

(Mean count $\log \mathrm{cfu} / \mathrm{ml} \pm \mathrm{SD}^{*}$ of three replications)

* Standard deviation

$* *<1$ was excluded from statistical analysis, only positive count values were included

There are significance differences $(P<0.05)$ between mean having different letters in the same column (same day)

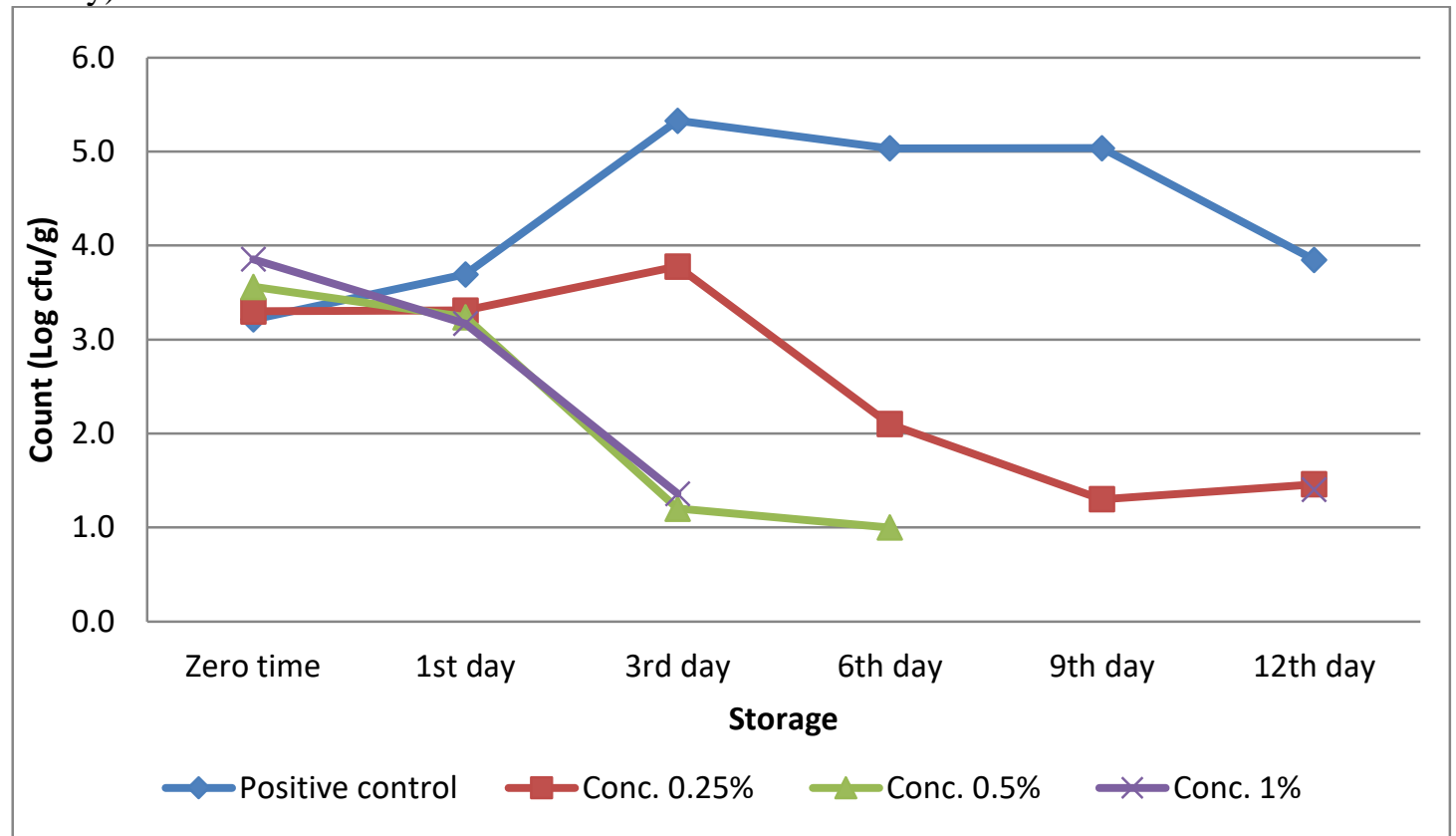

Fig. (1): Antibacterial effect of chitosan on Shigella strain inoculated in pasteurized milk

\section{DISCUSSION}

As shown in Table 1, 37\% of milk and $43 \%$ of kareish cheese samples were contaminated by suspected Shigella species when applied the conventional biochemical tests and after PCR confirmation. The occurrence of virulence Shigella species; was in two milk samples while four of kareish cheese samples were positive for virulence Shigella of the invC gene. About the ipaH gene, two samples of each milk and cheese possess the gene. Otherwise, four of them had both the virulence genes as shown in Table 3.

The genus Shigella belongs to the family Enterobacteriaceae and consists of four species; each of the species, with the exception of $S$. sonnei, is subdivided by serotype. Batt (1997) and Wachsmuth and Morris (1989) indicated that by means of human transmission, Shigella can contaminate several kinds of foods, included raw milk and some dairy products. 
In this study, the number of identified Shigella strains were 23; distributed as showen in Table 2, one strain of Shigella dysenteriae, three strains of Shigella flexneri and six strains of Shigella sonnei but Shigella boydii could not be detected in the examined milk samples. The number of $S$. dysenteriae and $S$. boydii were two and one, respectively. Otherwise, both $S$. flexneri and $S$. sonnei were five in the tested cheese. The culture-based techniques were used as the gold standard for the detection of Shigella spp. in various samples, but the conventional procedures required multiple subculture steps, biochemical and serological confirmation, which took about 7 days, and were time-consuming and laborious (Mokhtari et al., 2012). Virulent Shigella organisms cause the human illness known as bacillary dysentery, (shigellosis) causes mild diarrhea, fever, abdominal cramps and sever fluid loss. Hale et al. (1983) who was first described $S$. flexneri. It was established that the loss of the virulence plasmid results in a virulent strains and that the genes implicated in virulent functions are localized not only in the virulence plasmid but also in the chromosome. Uchiya et al. (1995) said that the virulence plasmid of $S$. flexneri has been implicated in invasion and intercellular spreading. In recent years, molecular technologies, such as PCR and real-time PCR assays, have been successfully applied to detect Shigella spp. PCR-based technologies have been successfully developed to detect Shigella from various food products and environment samples (Villalobo and Torres, 1998; Lin et al., 2010; Jiménez et al., 2010_and Law et al., 2014).

From Photo1 and Photo 2, it was found that of 23 identified Shigella strains only six harbour the invasive gene (invC) virulence gene but only four strains had chromosomal and plasmid-encoded virulence gene (ipaH) that involved in this study. This is in agreement with Mokhtari et al. (2012). The ipaH gene, coding an invasion- associated plasmid antigen, was present in multiple copies in both the chromosomes and the plasmids of all Shigella species, which could be selected as mark gene for detection of all Shigella strain ( $\mathrm{Vu}$ et al., 2004). The percentage of Shigella isolates and ipaH \& invC virulence genes demonstrated a marked pattern of seasonality, increasing in summer and related to the environment contamination. On the other hand, Shigella is considered a fastidious pathogen for bacteriological isolation, which in the context of indigenous micro flora and other substances makes detection less feasible (Jiménez et al., 2010).

PCR is considered a fast, highly sensitive and specific assay that quickly amplifies specific sequences of the target DNA from bacterial pathogens such as Shigellaspp. The target DNA is a specific sequence from a gene related to virulence mechanisms.

Epidemiological studies on Shigella have established that 10 cells are sufficient to be an infective dose according to ISO 6579 (2002). Legislation in many countries requires the absence of Shigella in 25-g amounts of foods, Egyptian Standards Requires complete absence of Shigella in 25 g sample (ESS, 2005), this proved that Shigella species of public health significant and thus milk and milk products should be free from Shigella species.

Regarding Table 4 and Fig 1, chitosan reduced the inoculated Shigella strain mean counts with highly significant effect at $6^{\text {th }}$ day reached to $2.10 \pm 0.17,1.00 \pm 0.30$ and $<1 \log \mathrm{cfu} / \mathrm{ml}$ for $0.25,0.5$ and $1 \%$ chitosan concentrations, respectively. Moreover, the mean count of positive control samples was $5.04 \pm 0.17$ on the same day comparing zero day and increased progressively during storage and reached to $1.30 \pm 0.30$ at $9^{\text {th }}$ day for $0.25 \%$ chitosan and $<1 \mathrm{log} \mathrm{cfu} / \mathrm{ml}$ for both 0.5 and $1 \%$. While at $12^{\text {th }}$ day chitosan concentration of $0.5 \%$ only was of highly significant, too and the other concentrations 
of chitosan 0.25 and $1 \%$ gave nearly the same mean counts $(1.46 \pm 0.15$ and 1.40 $\pm 0.17 \log \log \mathrm{cfu} / \mathrm{ml}$ ) and of moderate significance. Generally, the $0.5 \%$ chitosan concentration showed the highly reduction effect on the count and survival of the Shigella strain involved. The decrease on antibacterial activity as the concentration increases can be discussed in terms of the special arrangement of the polymer concentration yields a better molecular distribution in the solvent with a relatively small number interaction between the neighboring chains, so the charged sites available for external coupling are maximized (Halabalova et al., 2011 and Goy et al., 2016).

The disparity in lethality of chitosan shown among different reports may be attributed to the variation in chitosan property, food matrix and approaches of chitosan application. Chitosan also exerts other beneficial effects on food quality and maintaining freshness and sensory attributes. This study demonstrated the existence of Shigella in milk and kareish cheese and dispersion of different virulence genes among these isolates. Both PCR technique and conventional culture showed good analytical and diagnostic accuracy, all Shigella strains were positive by both methods. The molecular method showed a higher diagnostic sensitivity and a faster result as compared to the conventional culture.

\section{REFERENCES}

Aliasghari, A.; Khorasgani, M.R.; Vaezifar, S.; Rahimi, F.; Younesi, $H$. and Khoroushi, M. (2016): Evaluation of antibacterial efficiency of chitosan and chitosan nanoparticles on cariogenic streptococci: an in vitro study. Iran. J. Microbiol., 8 (2): 93-100.

Balouiri, M.; Sadiki, M. and Ibnsouda, S.K. (2016): Methods for in vitro evaluating antimicrobial activity: A review. J. Pharmaceutical Analysis, 6: 71-79.

Batt, C.A. (1997): Molecular diagnostic for dairy-borne pathogens. J. Dairy Sci. 80:220-229.

Dutta, S.; Chatterjee, A.; Dutta, P.; Rajendran, K.; Roy, S.; Pramanik, K.C. and Bhattacharya, S.K. (2001): Sensitivity and performance characteristics of a direct PCR with stool samples in comparison to conventional techniques for diagnosis of Shigella and entero-invasive Escherichia coli infection in children with acute diarrhoea in Calcutta, India. J. Med. Microbiol., 50: 667-674.

Eaton, P.; Fernandes, J.C.; Pereira, E.; Pintado, M.E. and Malcata (2008): F. X. Ultramicroscopy, 108, p.11281134.

ESS (Egyptian Standards Specifications) (2005): Microbiological criteria for foodstuffs.

Goy, C.; Rejane, Sinara, T.B.; Morais, Odilio and B.G. Assis, (2016): Evaluation of the antimicrobial activity of chitosan and its quaternized derivative on $\mathrm{E}$. coli and $\mathrm{S}$. aureus growth. Brasilian J. Pharmagonosy, 26: 122-127.

Halabalova, V.; Simek, L. and Mokrejs, P. (2011): Intrinsic viscosity and conformational parameters of chitosan chains. Rasayan J. Chem., 4: 223-241.

Hale, T.L. (1991): Genetic basis of virulence in Shigella species. Microbiol. Rev., 55:206-224.

Hall, P.A.; Ledenbach, L.; Flowers, R.S. (2001): Culture methods for enumeration of microorganisms. In: Downes FP, Ito K. (Eds.), Compendium of methods for the Microbiological Examination of Foods, Washington: American Public Health Association: 53-58.

Hale, T.L.; Sansonetti, P.J.; Schad, P.A.; Au stin, S. and Formal, S.B. (1983): Characterization of virulence plasmids and plasmid-associated outer membrane proteins in Shigella 
flexneri, Shigella sonnei, and Escherichia coli. Infect. Immun., 40: 340-350.

$H u, Z$. and Ganzle, M.G. (2018): Challenges and opportunities related to the use of chitosan as a food preservative. J. Appl. Microbiol., 126: 1318-1331.

ISO 6579 (2002): $4^{\text {th }}$ Ed. Microbiologygeneral Guidance on Methods for the detection of Shigella. International Organization for Standarization, Geneve, Switzerland.

Jiménez, K.B.; McCoy, C.B. and Achí, R. (2010): Detection of Shigella in lettuce by the use of a rapid molecular assay with increased sensitivity. Braz. J. Microbiol.; 41(4): 993-1000.

Kotloff, K.L.; Winickoff, J.P.; Ivanoff, B.; Clemens, J.D.; Swerdlow, D.L.; Sansonetti, P.J.; Adaka, G.K. and Levine, M.M. (1999): Global burden of Shigella infections: implications for vaccine development and implementation of control strategies. Bull. World Health Organ., 77: 651666.

Lampel, $\quad$ K. (2001): Shigella. In: In: Compendium of Methods for the Microbiological Examination of Foods. (Ed)., Downes, F.P., Ito, K., (Eds.) pp.: 381-385, Washington: American Public Health Association.

Lampel, $K$. and Orlandi, P. (2002): Polymerase chain reaction detection of invasive Shigella and Salmonella enterica in food. Methods in Molecular Biology., 179: 235-237.

Law, J.W.; Mutalib, A.B.; Chan, N.S.; K.G. and Lee, L.H. (2014): Rapid methods for the detection of foodborne bacterial pathogens: Principles, applications, advantages and limitations. Front. Microbiol. 5:770. doi: 10.3389/fmicb. 00770

Lin, W.S.; Cheng, C.M. and Van, K.T. (2010): A quantitative PCR assay for rapid detection of Shigella species in fresh produce. J. Food Prot., 73: 221233.
Martinez, L.R.; Mihu, M.R.; Han, G.; Frases, S.; Cordero, R.J.; Casadevall, A.; Friedman, A.J.; Friedman, J.M.; Nosanchuk, J.D. (2010): The use of chitosan to damage Cryptococcus neoformans biofilms. Biomaterials, 31, 669.

Mokhtari, W.; Nsaibia, S.; Majouri, D.; Ben Hassen, A.; Gharbi, A. and Aouni, M. (2012): Detection and characterization of Shigella species isolated from food and human stool samples in Nabeul, Tunisia, by molecular methods and culture techniques. J. Appl. Microbiol., 113: 209-222. doi: 10.1111/j.1365-2672.05324.

Ojha, S.C.; Yean, C.Y.; Ismail, A. and Singh, K.B. (2013): A Pentaplex PCR Assay for the Detection and Differentiation of Shigella Species. BioMed. Research Int., 9.

Peter, M.G. (1995): Applications and environmental aspects of chitin and chitosan. Pure and.Applied Chemistry, 32 (4): 629-40.

Raybaudi-Massilia R;Mosqueda-Melgar J.; Soliva-Fortuny, $R$. and MartinBelloso, O. (2009): Control of Pathogenic and Spoilage Microorganisms in Fresh-cut Fruits and Fruit 192 Juices by traditional and alternative natural antimicrobials. Compr. Rev. Food. Sci. Food Saf., 8(3): 157-180.

Rejane, C.G.; Douglas, D.B. and Odilio B.G. (2009): A review of the antimicrobial activity of chitosan. Polímeros: Ciência e Tecnologia, 19 (3): 241-247.

Rhee, S.; Wilson, K.T.; Gobert, A.; Nataro, J.P. and Fasano, A. (2001): The enterotoxic activity of Shigella enterotoxin 1 (ShET1) is mediated by inducible nitric oxide synthase activity. J. Pedi. Gastroenterol. Nutr., 33: 400-416.

Sethabutr, O.; Venkatesan, M.; Murphy, G.S.; Eampokalap, B.; Hoge, C.W. and Echeverria, P. (1993): Detection of Shigellae and Entero-invasive 
Escherichia coli by amplification of the invasive plasmid antigen HDNA sequence in patients with dysentery. $\mathrm{J}$. Infect. Dis., 167: 458-461.

Shakeel, A. and Saiqa, I. (2017): Chitosan. pp.:183: 232, Scrivener Pub. LLC.

Simunek, J.; Tishchenko, G.; Hodrová, B. and Bartonová, H. (2006): Folia Mocrobiol., 51: 306-308.

Tiwari, B.K.; Valdramidis, V. P.; O'Donnell, C.P.; Muthukumarappan, K.; Bourke, P. and Cullen, P.J. (2009): Application of natural antimicrobials for food preservation. J. Agric. Food Chem., 57: 5987-6000.

Uchiya, K.; Tobe, T.; Komatsu, K.; Suzuki, T .; Watarai, M.; Fukuda, I.; Yoshikawa, M. and Sasakawa, C. (1995): Identification of a novel virulence gene, virA, on the large plasmid of Shigella, involved in invasion and intercellular Microbiol., 17: 241-250.

Villalobo, E. and Torres, A. (1998): PCR for detection of Shigella spp. in mayonnaise. Appl. and Environ. Microbiol., 64, (4): 1242-1245.

Vu, D.T.; Sethabutr, O.; Von Seidlein, L.; Tran, V.T.; Do, G.C. and Bui, T.C. (2004): Detection of Shigella by a PCR assay targeting the ipaH gene suggests increased prevalence of shigellosis in NhaTrang, Vietnam. J. Clin. Microbiol., 42: 2031-2035. doi: 10.1128/JCM.42.5.2031-2035.

Wachsmuth, K. and Mprris, G.K. (1989): Shigella in Foodborne Bacterial Pathogens. Ed., Doyle M. P. Marcel Dekker, Inc.New York, N.Y, pp.: 448660.

\section{مدي تواجد ميكروبات الثيجلا في اللبن الخام والجبن القريش مع الاشارة الي جينات الضراوة زينب محمد عبد الحمبي ، منال حسن ثابت}

E-mail: z.shoret@gmail.com Assiut University web-site: www.aun.edu.eg

تم جمع . . 1 عينة من الحليب الخام و الجبن القريش من مز ارع مدينة أسيوط ومحلات الألبان. ثم تم عزل ميكروب الثيجلا

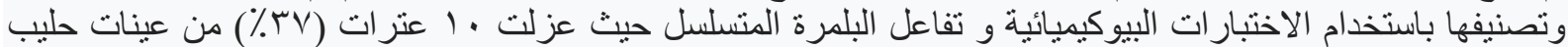

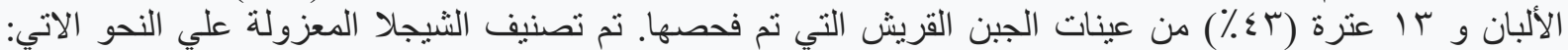

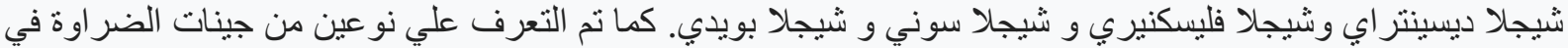

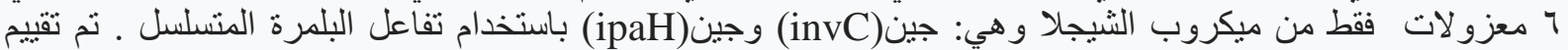

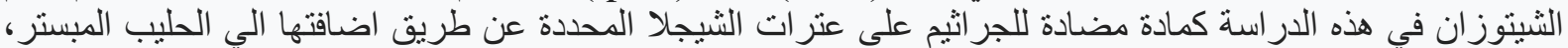

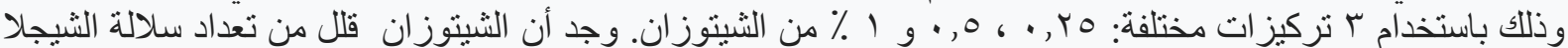

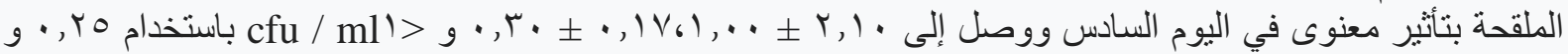

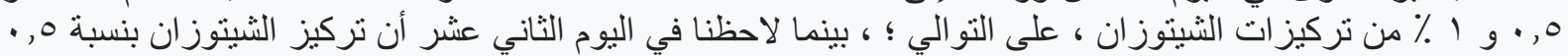

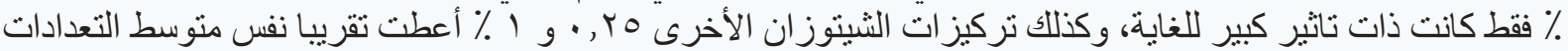

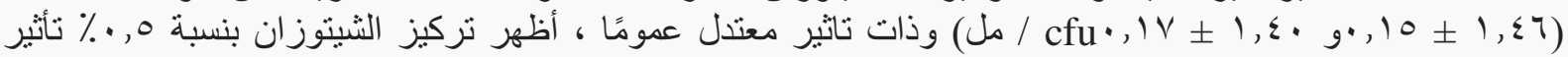
الخفض الثديد على عدد وبقاء سلالة الثيجلا المستخدمة بالتجربة. 